\title{
Political Campaign Success Predictors from Social Media Financing
}

\author{
Franco Curmi \\ University of Malta
}

\author{
Emanuel Said \\ University of Malta \\ Conrad Attard \\ University of Malta
}

Social media advertising has become an integral part of most political campaigns. This study investigates the funding and social media strategies adopted by politicians in the 2019 European Parliament Elections. We aggregate data across an EU member state, Malta, with a voting population of 330,000. This allows us to sample the entire candidate population $(n=41)$ to identify the strategy-variances and crowd behaviour. We then compare and contrast pre-election crowd behaviour with post-election outcome. Results are based on 84,320 data points that include 1) individual candidate advertising spend, 2) content submitted by candidates, 3) user generated content, 4) user interaction across multiple dimensions, and 5) actual voting results.

Results show that pre-election social media engagement is indicative of campaign success. Pre-election engagement is also related to campaign effectiveness based on lower cost per vote conversion. We also note that while spending more in Facebook ${ }^{\mathrm{TM}}$ advertising alone does not necessarily improve the candidate's likelihood of getting elected, however, the advertising cost conversion seems to have a significant influence on results. This suggests that the campaign's strategic efficiency is a key determinant of success.

Keywords: Political Marketing, Social Media Financing, Social Media Campaigns

\section{INTRODUCTION}

Political elections are a fundamental component of democratic systems. Over the past three decades, technology has disrupted many aspects of election campaigning and this has attracted strong attention from academics and political campaign practitioners (Saida, 2018; Jason, 2016; Bor, 2012). New technologies provided new tools (Verger, 2013; Vaccari, 2015) such as email campaigning, personalized apps to encourage grassroot activism, member relationship management systems that tame down management complexity and process automation to create personalized voter experiences from basic rulebased systems to complex AI-based personalisation. 
There have been many instances where new technologies were used in unethical ways in political campaigning (Berghel, 2018). On the other hand, if used responsibly, these tools can present a valuable resource for incumbents and prospective politicians to communicate and reach out to their communities in a more efficient and cheaper way then traditional communication channels such as television advertising. In principle, this easier access to reaching out, such as by using Facebook ${ }^{\mathrm{TM}}$ as a communication tool, should facilitate access for prospective politicians who do not have the power of incumbency or strong internal/external support. However, is the effectiveness of using Facebook ${ }^{\mathrm{TM}}$ for political campaigning dependent on the candidates spend in financing message-spread through paid advertising?

As part of Facebook ${ }^{\mathrm{TM}}$ 's effort to increase transparency in political campaigns, in 2019 Facebook $^{\mathrm{TM}}$ updated its advertising policy and is now making political adverts' data public. This includes the number of adverts that a candidate's page is running, the spend on each advert and results data on each advert including demographic data and advert's reach (Figure 1). For the first time, this allows us to compare and contrast relationships between campaign social media spending and campaign success across an entire competing political candidate cohort. In addition, we also aggregate and compare public data for each candidate's campaign such as number of posts, engagement for each post and user generated comments during the 5-week campaign prior to election day.

\section{FIGURE 1 \\ FACEBOOKTM UPDATED PAGE TRANSPARENCY DATA}

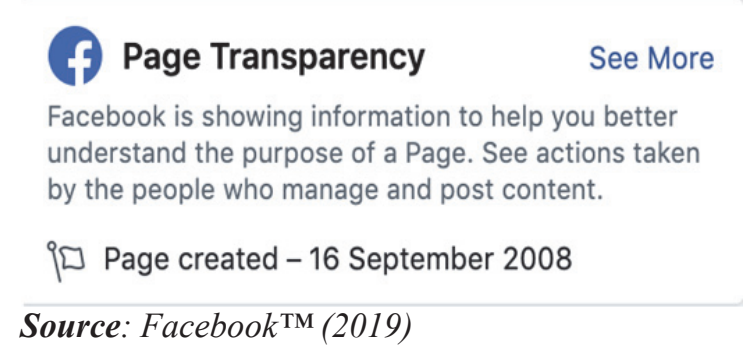

\section{CONTEXT}

In this study we set our lens on Malta, one of the smaller EU member states since its size allows us to investigate the entire cohort of political candidates in an EU country for the 2019 European Parliament Elections.

Malta is the southern European country with an area of $316 \mathrm{~km}^{2} .41$ candidates ran for election of six seats that represent Malta in the European Parliament. Of 371,643 registered voters 206,212 cast a valid vote. Five candidates had no party affiliation (independent) with the rest affiliated with one of 8 parties. Table 1 shows the distribution of the candidates across the parties and Figure 2 shows the gender distribution. 
TABLE 1

\section{NUMBER OF CANDIDATES AND POLITICAL PARTIES}

\begin{tabular}{|l|c|}
\hline Party & n \\
\hline AD & 2 \\
\hline Allejanza Bidla & 2 \\
\hline Brain Not Ego & 1 \\
\hline Imperium Europa & 1 \\
\hline Independent & 5 \\
\hline MPM & 2 \\
\hline PD & 4 \\
\hline PL & 14 \\
\hline PN & 10 \\
\hline Total & $\mathbf{4 1}$ \\
\hline
\end{tabular}

Source: Electoral Commission (2019)

Facebook ${ }^{\mathrm{TM}}$ is widely adopted across the country. $87 \%$ of the population makes regular use of Facebook $^{\mathrm{TM}}$. This makes Malta ranked the second highest in Europe's average of 65\% (Eurostat, 2019). This also makes Facebook ${ }^{\mathrm{TM}}$ well within the candidates' radar when they evaluate communication channel to use to reach out to their constituents.

\section{Existing Work}

The influence of social media on election outcomes has seen a surge in research over recent years as new tools and affordances emerged (Ceron, 2014; Housholder \& Lamarre, 2015; Rodrigues, 2017; Farkas, 2018). Larsen (2014) analysed social media content and engagement to understand the relation between the popularity of the social media pages and political content consumption in the light that political campaigning is nowadays 'always on' throughout the legislature. Results indicate that small parties and candidates are able to build momentum and adapt faster to a changing environment probably due to the ease of access that social media platforms afford. This contrasts with the funding required to build strong impact and reach out within cash-hungry social media platforms that is presented in Lindsey (2018).

Concurrently, the relationship between spending and campaign success has also attracted the attention of researchers for a long time. Sudulich and Wall (2010) investigated the relationships between campaign spending diversification and overall success with results showing that diversification of spending is associated with positive campaign results only in well-financed campaigns. Most of the existing studies however group advertising spends and channels together. For example, in their analysis Sudulich and Wall (2010) cluster together all advertisement, publicity, posters, other election material, office, transport, marketing and research, and campaign workers. In our study, we open up advertisement to focus on social media advertising spending and voter engagement as a single communication channel. This allows us to better understand the relationship between social media advertising spend, voter engagement and campaign success. 
FIGURE 2

DISTRIBUTION OF CANDIDATES ACROSS PARTIES, ELECTION OUTCOME AND GENDER

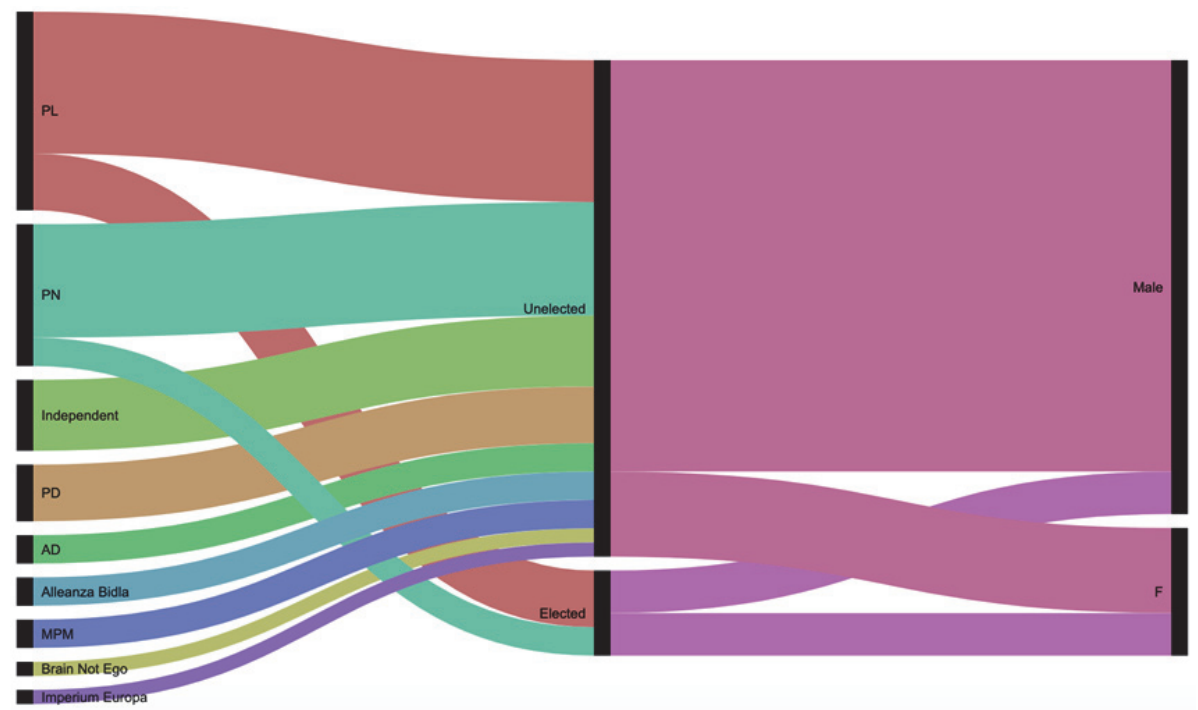

Source: Author's calculations

\section{METHOD}

We collect social media data during 5 weeks prior to European Parliament election day $26^{\text {th }}$ May 2019. This data included candidate lists, number of fans on page and daily posts. On election day we also stored a data snapshot of the interaction for each post within the previous 5-week campaign period, categorised and quantified the interaction types (e.g. Like, Love, Haha, Angry etc...), comments and shares for each post and number of fans (growth). On election day we also counted the number of political and non-political adverts that each candidate got approved during the campaign and the advertising spend for each candidate. This data was sourced from Facebook ${ }^{\mathrm{TM}}$ page transparency service. Our data collection generated 84,320 data points. We then use SPSS and Tableau for data analysis.

\section{RESULTS}

The resulting dataset covered a total of 41 European Parliament candidates. Six of these candidates got elected, representing two major Maltese political parties (out of a total of eight parties along with five independent candidates). Forty of these candidates had a Facebook ${ }^{\mathrm{TM}}$ page on which a level of interaction with followers occurred. Figure 3 shows the distribution across parties, election outcomes and Facebook $^{\mathrm{TM}}$ advertising spend $(€)$. On the other hand, Figure 4 highlights the relation between the election outcome and the cost per vote conversion. Initial statistics suggest a significant difference between those candidates who got elected and those who did not in terms of the average number of Facebook ${ }^{\mathrm{TM}}$ fans, ads, likes, comments and growth (see Table 2). 


\section{FIGURE 3}

\section{DISTRIBUTION ACROSS PARTIES, ELECTION OUTCOMES AND FACEBOOKTM}

ADVERTISING SPEND (€)

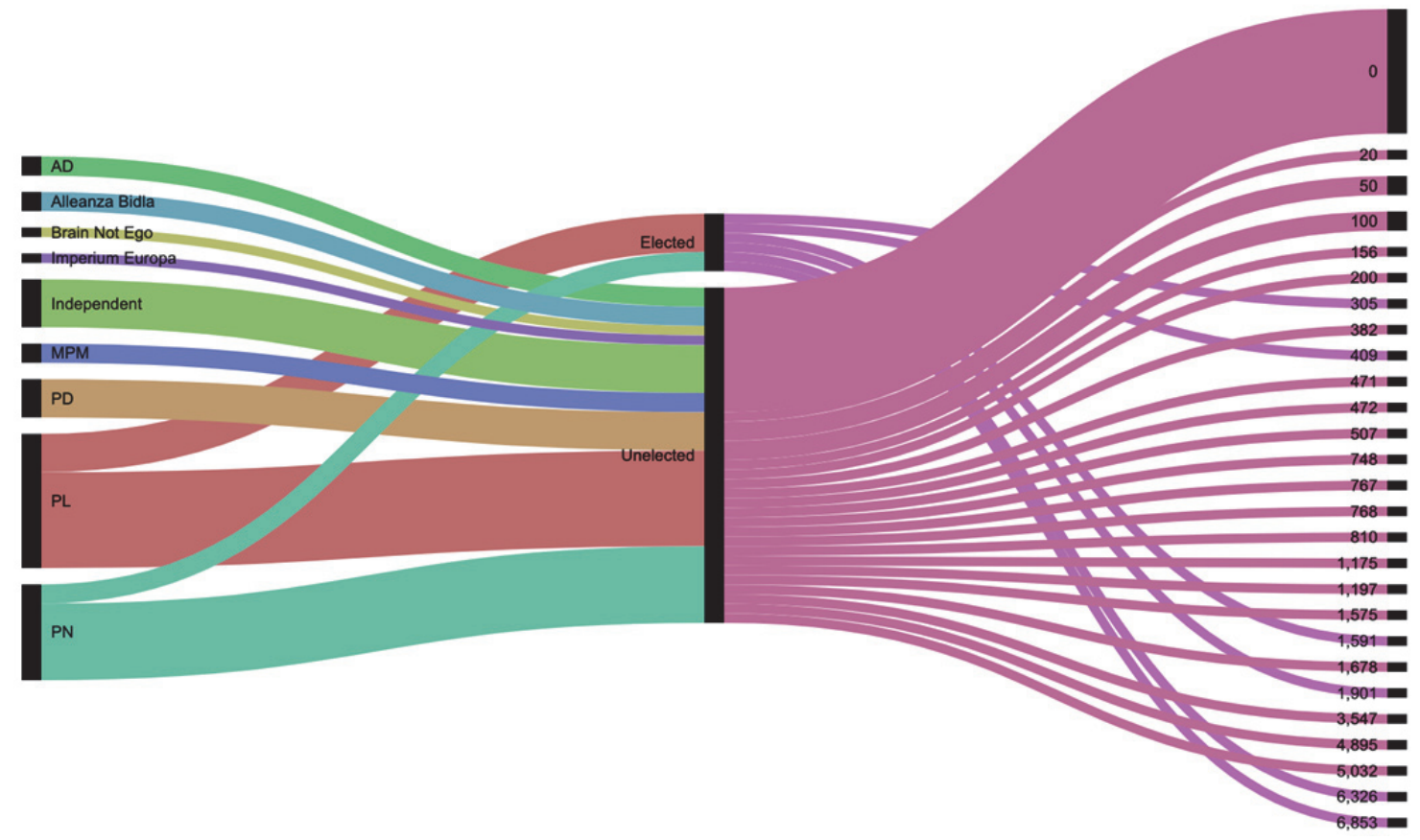

Source: Author's calculation

FIGURE 4

DISTRIBUTION OF CANDIDATES' ELECTION OUTCOME AND AVERAGE SPEND PER VOTE CONVERSION (€)

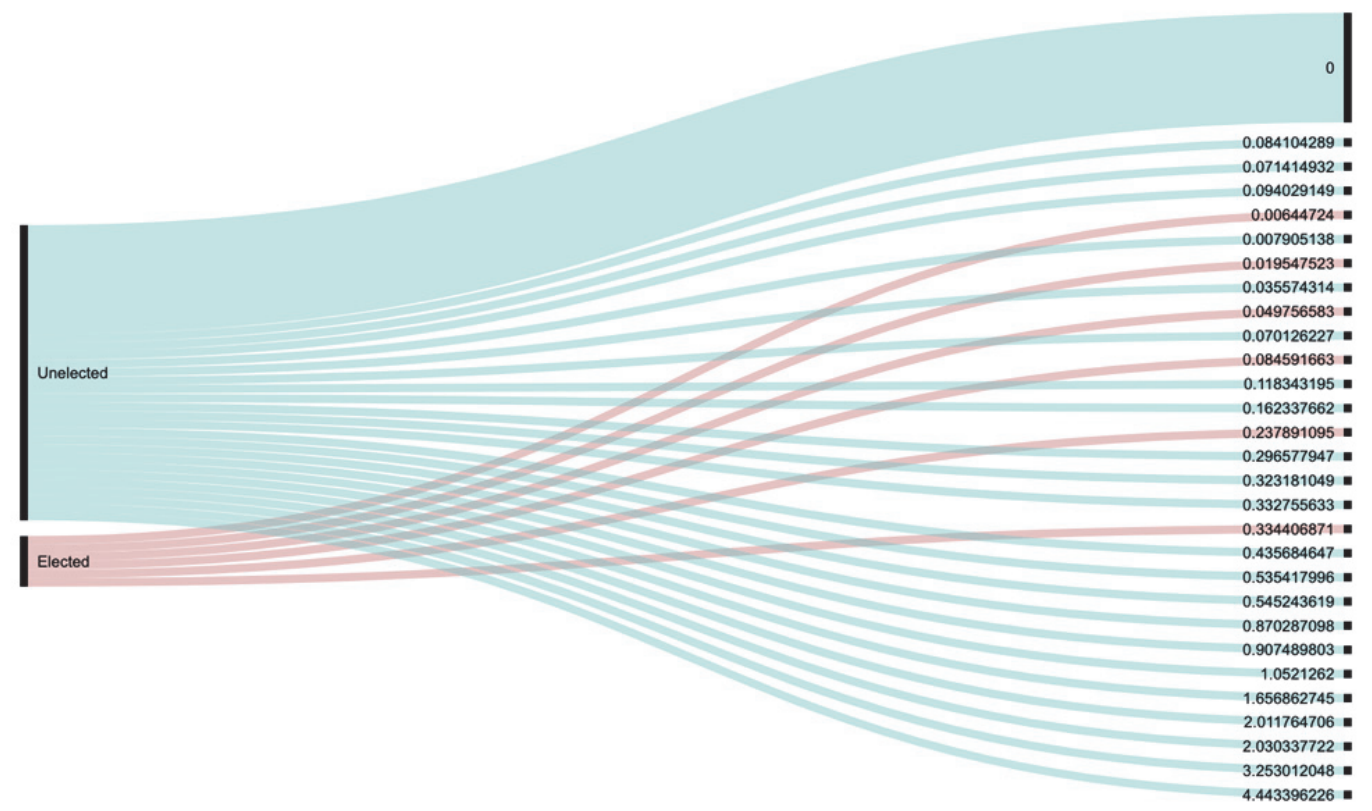

Source: Author's calculations 
TABLE 2

DIFFERENCES BETWEEN ELECTED AND NON-ELECTED

CANDIDATES - INDEPENDENT SAMPLES T-TEST

\begin{tabular}{|c|c|c|c|c|c|c|c|c|}
\hline \multicolumn{4}{|c|}{ Group Statistics } & \multicolumn{2}{|c|}{$\begin{array}{c}\text { Levene's Test for Equality } \\
\text { of Variances }\end{array}$} & \multicolumn{3}{|c|}{$\begin{array}{l}\text { t-test for Equality of Means } \\
\text { (equal variances assumed) }\end{array}$} \\
\hline Election Outcome & & Mean & Std. Deviation & F & Sig. & $t$ & $\mathrm{df}$ & Sig. (2-tailed) \\
\hline \multirow[t]{2}{*}{ Social media spend } & Elected & 2897.50 & 2933.06 & 13.813 & .001 & 3.115 & 39 & .003 \\
\hline & Unelected & 705.71 & 1281.92 & & & & & \\
\hline \multirow[t]{2}{*}{ Number of ads } & Elected & 82.67 & 56.03 & .205 & .653 & 2.098 & 39 & .042 \\
\hline & Unelected & 27.60 & 59.89 & & & & & \\
\hline \multirow[t]{2}{*}{ Average spend per ad (Euro) } & Elected & 29.14 & 13.90 & 1.975 & .168 & -.042 & 38 & .967 \\
\hline & Unelected & 29.88 & 42.46 & & & & & \\
\hline \multirow{2}{*}{$\begin{array}{l}\text { Average cost per vote } \\
\text { conversion (Euro) }\end{array}$} & Elected & 0.12 & 0.13 & 3.454 & .071 & -1.036 & 39 & .307 \\
\hline & Unelected & 0.55 & 1.01 & & & & & \\
\hline \multirow[t]{2}{*}{ Fans } & Elected & 30888.83 & 14809.79 & 18.127 & .001 & 5.054 & 17 & .000 \\
\hline & Unelected & 7919.62 & 5359.19 & & & & & \\
\hline \multirow[t]{2}{*}{ Page Performance Index } & Elected & 0.80 & 0.28 & .335 & .570 & .215 & 17 & .832 \\
\hline & Unelected & 0.77 & 0.31 & & & & & \\
\hline \multirow[t]{2}{*}{ Number of Likes } & Elected & 58492.33 & 18047.06 & 1.412 & .244 & 7.386 & 29 & .000 \\
\hline & Unelected & 11916.00 & 12831.33 & & & & & \\
\hline \multirow[t]{2}{*}{ Posts per day } & Elected & 5.11 & 1.75 & .252 & .619 & 1.148 & 29 & .260 \\
\hline & Unelected & 3.51 & 3.28 & & & & & \\
\hline \multirow[t]{2}{*}{ Post interaction } & Elected & 0.02 & 0.00 & 7.429 & .011 & -.556 & 29 & .583 \\
\hline & Unelected & 0.02 & 0.02 & & & & & \\
\hline \multirow[t]{2}{*}{ Average Weekly Growth } & Elected & 0.01 & 0.01 & .009 & .927 & .631 & 29 & .533 \\
\hline & Unelected & 0.01 & 0.02 & & & & & \\
\hline \multirow[t]{2}{*}{ Number of Comments } & Elected & 4414.67 & 1309.62 & .100 & .754 & 7.482 & 29 & .000 \\
\hline & Unelected & 980.92 & 934.94 & & & & & \\
\hline \multirow[t]{2}{*}{ Number of posts } & Elected & 184.00 & 63.12 & .252 & .619 & 1.148 & 29 & .260 \\
\hline & Unelected & 126.24 & 118.18 & & & & & \\
\hline \multirow[t]{2}{*}{ Growth (absolute) } & Elected & 1452.67 & 1146.13 & 10.287 & .003 & 4.186 & 29 & .000 \\
\hline & Unelected & 251.76 & 455.64 & & & & & \\
\hline \multirow[t]{2}{*}{ Engagement } & Elected & 0.08 & 0.04 & .036 & .851 & 1.322 & 29 & .197 \\
\hline & Unelected & 0.05 & 0.05 & & & & & \\
\hline
\end{tabular}

Source: Author's calculations

As each of these variables featured wide ranges, we investigated how the first count votes and total votes can be predicted using $\log 10$ transformed predictor variables. Using stepwise regression analysis, we tested how variables like fans, posts per day, number of posts, number of comments, growth, social media spend, average cost per vote, page performance index, number of likes, post interaction, average weekly growth and engagement could predict the number of first count (Table ) and total (Table 4) votes attained by a candidate on election day. Our analysis finds that in both cases, the prime predictor variable is the number of fans a candidate's Facebook ${ }^{\mathrm{TM}}$ profile attracts $(p<0.05)$. The average cost per vote is a second ranking predictor only in the case of first count votes $(p<0.05)$.

TABLE 3

STEPWISE REGRESSION MODEL FOR PREDICTING FIRST COUNT VOTES

\begin{tabular}{|c|c|c|c|c|c|c|c|c|c|c|c|}
\hline \multicolumn{4}{|c|}{ Model Summary $^{\mathrm{c}}$} & \multicolumn{2}{|c|}{ ANOVA } & \multicolumn{6}{|c|}{ Coefficients } \\
\hline \multirow[t]{2}{*}{ Model } & \multirow[t]{2}{*}{$\mathrm{R}$} & \multirow[t]{2}{*}{ R Square } & \multirow[t]{2}{*}{$\begin{array}{l}\text { Adjus ted } \\
\text { R Square }\end{array}$} & \multirow[t]{2}{*}{$\mathrm{F}$} & \multirow[t]{2}{*}{ Sig. } & \multirow[t]{2}{*}{ Predictors } & \multicolumn{2}{|c|}{ Unstandardized Coefficients } & \multirow{2}{*}{$\begin{array}{c}\begin{array}{r}\text { Standardized } \\
\text { Coefficients }\end{array} \\
\text { Beta }\end{array}$} & \multirow[t]{2}{*}{$\mathrm{t}$} & \multirow[t]{2}{*}{ Sig. } \\
\hline & & & & & & & B & Std. Error & & & \\
\hline 1 & $.783^{\mathrm{a}}$ & .614 & .586 & 22.234 & $.000^{\mathrm{a}}$ & L(10) Fans & 34643.067 & 7346.990 & .783 & 4.715 & .000 \\
\hline \multirow[t]{3}{*}{2} & \multirow[t]{3}{*}{$.847^{\mathrm{b}}$} & \multirow[t]{3}{*}{.717} & \multirow[t]{3}{*}{.673} & \multirow[t]{3}{*}{16.433} & \multirow[t]{3}{*}{$.000^{\mathrm{b}}$} & (Constant) & -100719.319 & 29433.067 & & -3.422 & .005 \\
\hline & & & & & & $\mathrm{L}(10)$ & 26342.031 & 7565.513 & .596 & 3.482 & .004 \\
\hline & & & & & & L(10) Average cost per vote conversion & -9303.288 & 4281.486 & -.372 & -2.173 & .049 \\
\hline
\end{tabular}

b. Predictors: (Constant), L(10) Fans, L(10) Average cost per vote

c. Dependent Variable: First count votes

Source: Author's calculations

106 Journal of Management Policy and Practice Vol. 20(5) 2019 
TABLE 4

STEPWISE REGRESSION MODEL FOR PREDICTING TOTAL COUNT VOTES

\begin{tabular}{|c|c|c|c|c|c|c|c|c|c|c|c|}
\hline \multicolumn{4}{|c|}{ Model Summary $^{\text {b }}$} & \multicolumn{2}{|c|}{ ANOVA } & \multicolumn{6}{|c|}{ Coefficients } \\
\hline \multirow[t]{2}{*}{ Model } & \multirow[t]{2}{*}{$\mathrm{R}$} & \multirow[t]{2}{*}{ R Square } & \multirow[t]{2}{*}{$\begin{array}{l}\text { Adjusted R } \\
\text { Square }\end{array}$} & \multirow[t]{2}{*}{ F } & \multirow[t]{2}{*}{ Sig. } & \multirow[t]{2}{*}{ Predictors } & \multicolumn{2}{|c|}{ Unstandardized Coefficients } & \multirow{2}{*}{$\begin{array}{c}\begin{array}{r}\text { Standardized } \\
\text { Coefficients }\end{array} \\
\text { Beta }\end{array}$} & \multirow[t]{2}{*}{$\mathrm{t}$} & \multirow[t]{2}{*}{ Sig. } \\
\hline & & & & & & & B & Std. Error & & & \\
\hline \multirow[t]{2}{*}{1} & \multirow[t]{2}{*}{$.805^{\mathrm{a}}$} & \multirow[t]{2}{*}{.648} & \multirow[t]{2}{*}{.621} & \multirow[t]{2}{*}{23.955} & \multirow[t]{2}{*}{$.000^{\mathrm{b}}$} & (Constant) & -120544.322 & 28162.051 & & -4.280 & .001 \\
\hline & & & & & & L(10) Fans & 33934.657 & 6933.355 & .805 & 4.894 & .000 \\
\hline
\end{tabular}

a. Predictors: (Constant), L(10) Fans

b. Dependent Variable: Total votes

\section{Source: Author's calculations}

At this stage we investigated what actions would lead for candidates to boost the number of fans on their Facebook ${ }^{\mathrm{TM}}$ profile. In the same fashion, we tested out the same predictor variables using a stepwise regression model approach, and find that the total number of likes, engagement, number of comments and post interaction account can predict the number of Facebook ${ }^{\mathrm{TM}}$ fans a candidate's profile can attract during an electoral campaign $(p<0.05)$. Similar tests to predict the average cost per vote conversion suggest that social media spending, number of likes, engagement and growth are very good predictors $(p<0.05)$ (Table 6). The above analysis helps us propose an initial conceptual model (Figure 5) that explains how electoral candidates perform based on their engagement with audiences on Facebook ${ }^{\mathrm{TM}}$ as a modern medium for electoral campaigning.

TABLE 5

\section{STEPWISE REGRESSION MODEL FOR PREDICTING THE NUMBER OF FACEBOOKTM FANS FOR AN ELECTORAL CANDIDATE}

\begin{tabular}{|c|c|c|c|c|c|c|c|c|c|c|c|}
\hline \multicolumn{4}{|c|}{ Model Summary $^{\mathrm{e}}$} & \multicolumn{2}{|c|}{ ANOVA } & \multicolumn{6}{|c|}{ Coefficients } \\
\hline \multirow[t]{2}{*}{ Model } & \multirow[t]{2}{*}{$\mathrm{R}$} & \multirow[t]{2}{*}{ R Square } & \multirow[t]{2}{*}{$\begin{array}{l}\text { Adjus ted R } \\
\text { Square }\end{array}$} & \multirow[t]{2}{*}{$\mathrm{F}$} & \multirow[t]{2}{*}{ Sig. } & \multirow[t]{2}{*}{ Predictor } & \multicolumn{2}{|c|}{$\begin{array}{l}\text { Unstandardized } \\
\text { Coefficients }\end{array}$} & \multirow{2}{*}{$\begin{array}{c}\begin{array}{r}\text { Standardized } \\
\text { Coefficients }\end{array} \\
\text { Beta }\end{array}$} & \multirow[b]{2}{*}{$\mathrm{t}$} & \multirow[b]{2}{*}{ Sig. } \\
\hline & & & & & & & $\mathrm{B}$ & Std. Error & & & \\
\hline \multirow[t]{2}{*}{1} & \multirow[t]{2}{*}{$.800^{\mathrm{a}}$} & \multirow[t]{2}{*}{.641} & \multirow[t]{2}{*}{.615} & \multirow[t]{2}{*}{24.955} & \multirow[t]{2}{*}{$.000^{\mathrm{b}}$} & (Constant) & 1.178 & .585 & \multirow[b]{2}{*}{.800} & 2.013 & .064 \\
\hline & & & & & & L(10) Number of likes & .668 & .134 & & 4.996 & .000 \\
\hline \multirow[t]{3}{*}{2} & \multirow[t]{3}{*}{$.995^{\mathrm{b}}$} & \multirow[t]{3}{*}{.990} & \multirow[t]{3}{*}{.988} & \multirow[t]{3}{*}{624.964} & \multirow[t]{3}{*}{$.000^{\mathrm{c}}$} & (Constant) & -1.054 & .148 & & -7.130 & .000 \\
\hline & & & & & & L(10) Number of likes & .921 & .026 & 1.104 & 34.894 & .000 \\
\hline & & & & & & L(10) Engagement & -.972 & .046 & -.664 & -20.997 & .000 \\
\hline \multirow[t]{4}{*}{3} & \multirow[t]{4}{*}{$.998^{\mathrm{c}}$} & \multirow[t]{4}{*}{.996} & \multirow[t]{4}{*}{.995} & \multirow[t]{4}{*}{1064.849} & $.000^{\mathrm{d}}$ & (Constant) & -1.034 & .093 & & -11.124 & .000 \\
\hline & & & & & & L(10) Number of likes & .782 & .035 & .937 & 22.628 & .000 \\
\hline & & & & & & L(10) Engagement & -.985 & .029 & -.673 & -33.743 & .000 \\
\hline & & & & & & L(10) Number of comments & .174 & .038 & .189 & 4.583 & .001 \\
\hline 4 & $.999^{d}$ & .997 & .997 & 1094.580 & $.000^{\mathrm{e}}$ & (Constant) & -1.099 & .084 & & -13.047 & .000 \\
\hline & & & & & & L(10) Number of likes & .813 & .032 & .974 & 25.125 & .000 \\
\hline & & & & & & L(10) Engagement & -.936 & .033 & -.640 & -28.786 & .000 \\
\hline & & & & & & L(10) Number of comments & .126 & .038 & .137 & 3.287 & .007 \\
\hline & & & & & & $\mathrm{L}(10)$ Post interaction & -.080 & .034 & -.050 & -2.329 & .040 \\
\hline a. Predic & (Constar & $\mathrm{L}(10) \mathrm{Nur}$ & er of likes & & & & & & & & \\
\hline b. Predic & Constar & L(10) Nur & er of likes, & 10) Enga & & & & & & & \\
\hline c. Predic & (Constar & ), L(10) Nur & er of likes, & L(10) Engas & $\mathrm{t}, \mathrm{L}(10)$ & Imber of comments & & & & & \\
\hline d. Predic & Constar & $\mathrm{L}(10) \mathrm{Nur}$ & $r$ of likes, & L(10) Engas & $\mathrm{L}(10)$ & mber of comments, $\mathrm{L}(10)$ & ction & & & & \\
\hline Depen & ariable & (10) Fans & & & & & & & & & \\
\hline
\end{tabular}

Source: Author's calculations 
TABLE 6

STEPWISE REGRESSION MODEL FOR PREDICTING THE AVERAGE COST PER VOTE CONVERSION FOR AN ELECTORAL CANDIDATE

\begin{tabular}{|c|c|c|c|c|c|c|c|c|c|c|c|}
\hline \multicolumn{4}{|c|}{ Model Summary $^{\mathrm{e}}$} & \multicolumn{2}{|c|}{ ANOVA } & \multicolumn{6}{|c|}{ Coefficients } \\
\hline \multirow[t]{2}{*}{ Model } & \multirow[t]{2}{*}{$\mathrm{R}$} & \multirow[t]{2}{*}{ R Square } & \multirow[t]{2}{*}{$\begin{array}{l}\text { Adjus ted } \\
\text { R Square }\end{array}$} & \multirow[t]{2}{*}{$\mathrm{F}$} & \multirow[t]{2}{*}{ Sig. } & \multirow[t]{2}{*}{ Predictors } & \multicolumn{2}{|c|}{$\begin{array}{l}\text { Unstandardized } \\
\text { Coefficients }\end{array}$} & \multirow{2}{*}{$\begin{array}{c}\text { Standardized } \\
\text { Coefficients }\end{array}$} & \multirow[t]{2}{*}{$\mathrm{t}$} & \multirow[t]{2}{*}{ Sig. } \\
\hline & & & & & & & B & Std. Error & & & \\
\hline 1 & $.518^{\mathrm{a}}$ & .268 & .216 & 5.125 & $.040^{\mathrm{b}}$ & L(10) Social media spend & .629 & .278 & .518 & 2.264 & .040 \\
\hline \multirow[t]{2}{*}{2} & \multirow[t]{2}{*}{$.751^{\mathrm{b}}$} & \multirow[t]{2}{*}{.564} & \multirow[t]{2}{*}{.497} & \multirow[t]{2}{*}{8.411} & \multirow[t]{2}{*}{$.005^{\mathrm{c}}$} & (Constant) & .214 & 1.202 & & .178 & .861 \\
\hline & & & & & & L(10) Social media spend & .923 & .244 & .759 & 3.790 & .002 \\
\hline \multirow[t]{4}{*}{3} & \multirow[t]{4}{*}{$.840^{\mathrm{c}}$} & \multirow[t]{4}{*}{.706} & \multirow[t]{4}{*}{.632} & \multirow[t]{4}{*}{9.597} & \multirow[t]{4}{*}{$.002^{\mathrm{d}}$} & (Constant) & 2.742 & 1.470 & & 1.865 & .087 \\
\hline & & & & & & L(10) Social media spend & .908 & .208 & .747 & 4.358 & .001 \\
\hline & & & & & & L(10) Number of likes L(10) & -1.156 & .278 & -.784 & -4.161 & .001 \\
\hline & & & & & & Engagement & 1.095 & .455 & .423 & 2.404 & .033 \\
\hline \multirow[t]{4}{*}{4} & \multirow[t]{4}{*}{$.910^{\mathrm{d}}$} & \multirow[t]{4}{*}{.828} & .765 & 13.207 & $.000^{\mathrm{e}}$ & (Constant) & 3.035 & 1.180 & & 2.571 & .026 \\
\hline & & & & & & L(10) Social media spend & .894 & .167 & .735 & 5.362 & .000 \\
\hline & & & & & & L(10) Number of likes L(10) & -.559 & .308 & -.379 & -1.814 & .097 \\
\hline & & & & & & L(10) Growth & -.880 & .315 & -.605 & -2.789 & .018 \\
\hline
\end{tabular}

a. Predictors: (Constant), L(10) Social media spend

b. Predictors: (Constant), L(10) Social media spend, L(10) Number of likes

c. Predictors: (Constant), L(10) Social media spend, L(10) Number of likes, L(10) Engagement

d. Predictors: (Constant), L(10) Social media spend, L(10) Number of likes, L(10) Engagement, L(10) Growth

e. Dependent Variable: L(10) Average cost per vote conversion

Source: Author's calculations

FIGURE 5

PROPOSED CONCEPTUAL MODEL: DETERMINANTS OF FIRST COUNT VOTE PERFORMANCE IN ELECTORAL CAMPAIGNS BASED ON FACEBOOKTM AS A COMMUNICATIONS MEDIUM $^{\mathrm{T}}$

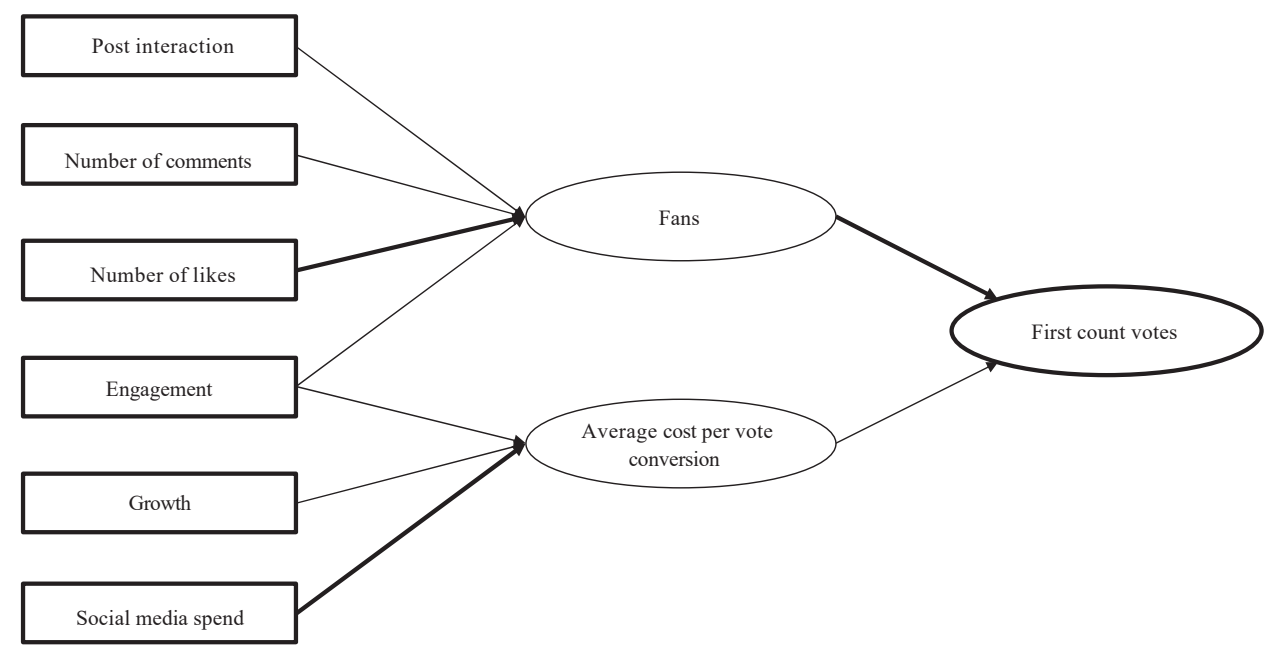

Source: Author's calculations 


\section{DISCUSSION}

While candidates who did not generate engagement on social media fared poorly, the average cost per vote suggests that some campaigns were highly inefficient. We define campaign efficiency as the average cost for converting one vote. Campaign efficiency seems to be a key indicator of message effectiveness. The distribution in Figure 4 suggests that the communication message is an essential element. In the future, a more detailed content analysis may give us deeper insight on how message effectiveness decreases social media advertising costs.

We observe that the two most voted candidates were also among the least to invest in Facebook ${ }^{\mathrm{TM}}$ advertising. At the same time, they were among the top candidates for engagement and user generated content (UGC). This engagement was generated through regular Facebook ${ }^{\mathrm{TM}}$ posts that spread organically and increased campaign efficiency by lowering costs. This mechanism indicates that campaign success is not necessarily dependent on Facebook ${ }^{\mathrm{TM}}$ advertising even in a small country that has a high degree of Facebook ${ }^{\mathrm{TM}}$ adoption. Our observation should not be interpreted as Facebook ${ }^{\mathrm{TM}}$ adverts do not contribute to campaign success. Indeed, an observation of the other four successful candidates who invested heavily in Facebook ${ }^{\mathrm{TM}}$ advertising suggest that paid adverts contributed to reaching out beyond the limitations of an otherwise small-impact organic reach.

\section{LIMITATIONS}

We are aware of a number of limitations to the study that are relevant to highlight for those interested in extending this work. This study investigates the effect of social media advertising on a national election. This research does not attribute any influence from other campaign communication channels such as print adverts, SMS messaging and email campaigns among others. The work takes the assumption that the results are influenced from social media advertising. The study also investigates the entire voting and candidate population on one country. As such, the results may be reflecting influences from factors that are country specific. In this light, we hope that future work will replicate similar studies in other elections, geographies and cultures. We consider our work as a contribution in this direction. We also do not factor-in the effect of party grouping on result. In another work-in-progress study, we are extrapolating any hidden unconventional influencing factors such as the use of trolls, that was widely mentioned in existing related literature, to influence comments and the effect that this has, if any, on election outcomes.

\section{CONCLUSIONS}

We hope that this small full population study could provide a blueprint for replication in other countries and elections to better understand how democracies are tangibly being shaped by election campaign investments, new communication channels and voter engagement prior to elections. While more research needs to be conducted in this area to gain more robust outcomes through larger samples and study replication, the results indicate that the number of social media followers is strongly related to campaign outcome. Additionally, while the total Facebook ${ }^{\mathrm{TM}}$ advertising spend did not feature as related to election outcome, however, the cost of advert conversion is strongly related to election outcome. This suggests that campaign efficiency is a most important feature that should be monitored in the runup to an election. Future work that further investigates this is expected to include measures of message believability, adverts' look and feel and the adopted strategy type.

\section{ACKNOWLEDGEMENTS}

We thank all the volunteers who wrote and provided helpful comments on previous versions of this document.

Journal of Management Policy and Practice Vol. 20(5) 2019109 


\section{REFERENCES}

Bor, S. E., \& Payne, J.G. (2014). Using Social Network Sites to Improve Communication Between Political Campaigns and Citizens in the 2012 Election. American Behavioral Scientist, 58(9), $1195-213$.

Berghel, H. (2018). Malice Domestic: The Cambridge Analytica Dystopia. Computer, 51(5), 84-89.

Ceron, A., Curini, L., Iacus, S.M., Porro, G., Graham, M., Schroeder, R., \& Taylor, G. (2014). Every Tweet Counts? How Sentiment Analysis of Social Media Can Improve Our Knowledge of Citizens' Political Preferences with an Application to Italy and France. New Media \& Society, 16(2), 340-58.

Erdody, L. (2018) Campaigns Boost Investment in Social Media Ads: TV Still Key but Increasingly Less so. Indianapolis Business Journal, 39(3), 37.

Eurostat. (2019). 2019. Eurostat. Retrieved September 1, 2019, from http://appsso.eurostat.ec.europa.eu/nui/submitViewTableAction.do/

Farkas, J., \& Schwartz, S. (2018). Please Like, Comment and Share Our Campaign! Nordicom Review, 39(2), 19-33.

Housholder, E., \& Lamarre, H.L. (2015). Political Social Media Engagement: Comparing Campaign Goals with Voter Behavior. Public Relations Review, 41(1), 138-40.

Jamil, S. (2018). Politics in a Digital Age: The Impact of New Media Technologies on Public Participation and Political Campaign in Pakistan's 2018 Elections - A Case Study of Karachi. Global Media Journal, 16(31), 1.

Martin, J. A. (2016). Digital Platforms and Differential Gains: Campaign News, Online Expression, and Political Participation. Electronic News, 10(4), 243-259.

Rodrigues, U. M. M., \& Niemann, M. (2017). Social Media as a Platform for Incessant Political Communication: A Case Study of Modi's "Clean India" Campaign. International Journal of Communication, 11, 3431-3453.

Sudulich, M., \& Wall, M. (2011) How Do Candidates Spend Their Money? Objects of Campaign Spending and the Effectiveness of Diversification. Electoral Studies, 30(1), 91-101.

Vaccari, C., Valeriani, A., Barbera, P., Bonneau, R., Jost, J., Nagler, J., \& Tucker, J. (2015). Political Expression and Action on Social Media: Exploring the Relationship Between Lower- and HigherThreshold Political Activities Among Twitter Users in Italy. Journal of Computer-Mediated Communication, 20(2), 221-239.

Vergeer, M., \& Liesbeth, H. (2013) Campaigning on Twitter: Microblogging and Online Social Networking as Campaign Tools in the 2010 General Elections in the Netherlands. Journal of Computer-Mediated Communication, 18(4), 399-419. 